only known exception to this general rule is in Struthiones, where the old feather is carried for some time at the tip of the new.

Although statements have recently been made (Lillie and $J u_{h n^{2}}$ ) saying that it is not yet known whether the pulp of a feather resumes activity prior to shedding of the old feather, it is a well-known fact (Lynds Jones ${ }^{3}$, Cossar Ewart ${ }^{4}$ and others) that in young chicks and ducklings, the first generation feather is carried for some time at the tip of the succeeding definitive feather. Again, in adult fowls and ducks, if feathers are plucked near the moulting period, the new feather is invariably pulled away attached to its predecessor. This is unavoidable owing to the method of formation of the new feather. In nestling down, there is definite continuity between barbs of the new feather and the calamus of the old one, and in addition, the developing barbs are so constricted within the calamus of the old feather, that they usually show a distinct curve distally for some time after the old feather has been shed.

In definitive feathers, the new feather is always formed within the base of the old (except, of course, during regeneration following deliberate plucking). This is due $(a)$ to the outermost intermediate cells of the 'collar' cornifying to form the base of the calamus, instead of the whole of the stratum intermedium cornifying en masse, as it does more distally, while $(b)$ the median layers form a second sheath within the calamus, and $(c)$ the innermost layers form the ridges from which the barbs of the new feather arise. This process is described in detail in a paper now in press.

From this method of replacement of a feather, the lower umbilicus could not be completely sealed when the feather is fully grown. It is true that feather caps form as the pulp withdraws when the feather is nearing maturity, but these do not extend to the actual base. A minute papilla projects within the inferior umbilicus while the feather is attached to the bird, limited in its extension by the last feather cap, and it is from this papilla that the new feather grows. If the old feather is plucked when fully mature, but before the new feather has commenced to form, then this remnant of the previously extensive pulp is left behind in the follicle, so that the impression of an entirely pulpless and sealed feather is obtained.

It is therefore clear that these facts of the inferior umbilicus of the feather remaining unsealed, and the new feather pushing out the old, cannot be regarded as peculiar to Sphenisciformes or to Struthioniformes.

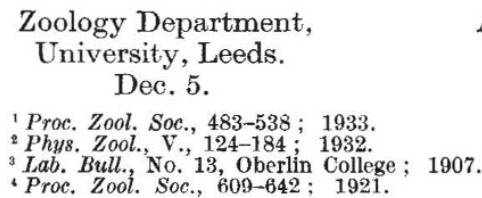

\section{Occurrence of Limnocnida in the Periyar Lake, Travancore}

ON June 4 last, I was surprised to find a number of fresh-water medusæ in the Periyar Lake in Travancore. From the shape of the manubrium and the presence of the gonads on the manubrium, and the shape and the arrangement of the nematocysts, the medus:e undoubtedly belong to the genus Limnocnida which has previously been recorded from India. The Periyar Lake about ten square miles in extent, has been formed by damming at its source in the Western Ghats the River Periyar, which flows westwards. Although the river fluctuates with the seasons, the lake contains deep water all the year round. It is noteworthy that fresh-water medusæ were found by Mr. S. P. Agharkar, but were in a river system which flows eastwards across the continent and enters the Bay of Bengal.

The Periyar Lake is situated at an elevation of three to four thousand feet and is sixty miles from the west coast of India as the crow flies. All the medusæ I saw were about the same size and very much smaller than those discovered by Mr. Agharkar. Mr. Agharkar's specimens measured 1.75 mm. when young, $15 \mathrm{~mm}$. when adult. The smallest of $\mathrm{my}$ specimens, however, measures $4.2 \mathrm{~mm}$. in diameter and the largest $4.9 \mathrm{~mm}$. in diameter and $2.2 \mathrm{~mm}$. in height, with tentacles measuring $1.6 \mathrm{~mm}$. So far, they have received only a cursory examination.

I believe the occurrence of Limnocnida has only been recorded from one area in India previously, that is, in the headwaters of the Kistna River and the neighbourhood, 650 miles from Periyar. Whether the species inhabiting the Periyar Lake is the same as that described by Dr. Annandale or a new species can only be determined after a proper examination of the collection.

Claybrooke, Kilpauk,

Phyllis Seymour Darlinc.

Madras.

Dec. 13.

\section{Local Variation in Habits of the Lizard, Amblyrhyncus cristatus}

ON a recent visit to the Galapagos Archipelago I noticed a point concerning Amblyrhyncus cristatus, an aquatic species, which might be of interest as a footnote to Darwin's observations on the same reptile.

In "The Voyage of the Beagle", Darwin says: "I several times caught this same lizard, by driving it down to a point, and though possessed of such perfect powers of diving and swimming, nothing would induce it to enter the water ; and as often as I threw it in, it returned in the manner above described".

I tried this same experiment myself on Albemarle Island, and found the reptile returned to dry land at great speed, but on Indefatigable Island, on the contrary, the lizards not only held no prejudice against entering the water, but even proceeded to do so as quickly as possible on being approacheda curious example of local variation.

Darwin attributes their reluctance to enter the water to the presence of sharks, but it is singular that I found sharks more numerous around Indefatigable Island than elsewhere in this archipelago.

$$
\text { J. G. Wyatt Tilby. }
$$

\section{5, Princes Court, \\ Hampstead, N.W.3.} Dec. 26.

Simultaneous Travel of a Surge of Stress and a Group of High-Frequency Waves of Stress in a Steel Wire

IN previous communications, it has been shown how the frequency of longitudinal vibration of a steel wire may be measured ${ }^{1}$ and also how the speed of travel of a surge of stress in a steel wire may be measured directly ${ }^{2}$. From each of these methods the value of Young's modulus may be found, and the 